\title{
The Construction of Full Coverage of Clean Culture in Colleges and Universities and Its Realization*
}

\author{
Chunxia Jiang \\ Guilin University of Aerospace Technology \\ Guilin, China
}

\author{
Hong $\mathrm{Yu}$ \\ Guangxi Science \& Technology Normal University \\ Laibin, China
}

\author{
Jiajue Fang** \\ Guangxi Science \& Technology Normal University \\ Laibin, China \\ **Corresponding Author
}

\begin{abstract}
Aiming at the problems in the construction of party conduct and clean governance in college including "Dividend Irrelevant Theory", unclear main body responsibility in probity construction and the integrative development with probity construction and construction of professional disciplines, it is extremely urgent to construct the full coverage of honest party conduct, clean political atmosphere, clean culture and clean professional ethos, new thought and new path for integrative and coordinated development as well as establish the "trinitarian" joint-control mode of cadre clean governance, teacher clean teaching and student clean learning so as to solve the problems including "dividend irrelevant theory", "impunity theory", "mismatch" and "trochee" and comprehensively construct clean college.
\end{abstract}

Keywords-clean culture of college and university; full coverage; realization path

\section{INTRODUCTION}

The current era is an uncorrupted era as well as the cultural era, so anti-corruption has become the public's demand. As the places to cultivate talents, colleges and universities are the habitat of culture and a key stage for young students to grow into talents. This stage is the period when students' ideological concepts, value orientation and spiritual outlook take shape. We must educate and guide them to form the correct outlook on life, world outlook and values, found ideals and beliefs, temper noble character, and buckle the first button of life to lay a solid foundation for growth and development. It is necessary to infiltrate the incorrupt education into college education. This is not only related to the growth of individuals, but also concerned to the party, the people, the political style, the social wind, which is the necessity of the times and the colleges and universities.

*This article is funded by "the study of development of Guangxi international service industry facing ASEAN (2018KY0695)", the project of basic ability promotion of young teachers of Guangxi colleges in 2018

\section{SOLVING THE PROBLEMS IN CONSTRUCTION OF TRINITARIAN ClEAN CULTURE OF COLLEGE}

\section{A. Problem of "Dividend Irrelevant Theory"}

In colleges, the non-party and non-leading cadre teachers and students think that the construction of party conduct and clean governance has nothing to do with themselves and that the party building is the matter of party members while the construction of party conduct and clean governance is the matter of leaders which have nothing to do with themselves. Of course, that is to say that such dividend irrelevant theory mixes the two concepts including probity education and clean politics education and lacks understanding on the importance of probity education and clean politics education. Although the probity education and clean politics education have consistent direction, there are also differences. The clean politics education mainly aims at the mass party member leading cadres while the probity education possesses popularity which is the requirement for all the masses and shall be carried forward and inherited by the young students. The cultivation of honest awareness of college students and the building of selfhonest habits of college students concern the construction of future cadre team and whether the next generation can realize clean governance. The Ministry of Education has put the probity education on the agenda and issued the Opinion on Comprehensive Development of Probity Education in Primary Schools, Middle Schools and Colleges which can comply with the objective of be strict with oneself required to be achieved by the "comprehensively strengthening Party self-discipline". Therefore, such "dividend irrelevant theory" obviously cannot comply with the new requirement of strengthening party conduct and clean governance under new situations.

\section{B. Problem of Full Coverage}

In colleges, although the consensus has been reached in theory, there are still problems arising from the works of probity education including unclear concept, unclear main body and unclear main body responsibility, etc as well as the phenomenon of impracticable responsibility realization 
including "same responsibility between party and government and double responsibilities for one post", the confusion where the frontline cadres "do not know whom they shall be finally responsible for" and the problem where they do not know whom they shall report to when facing "same responsibilities between party and government. At the same time, there are also the problems including leader probity awareness weakening, duty buckpassing which will cause the "same responsibilities between party and member" to fall to ground. Therefore, construction of clean colleges and insisting of principal accountability system under leadership of the party committee are the basis principles for well managing the colleges with socialism with Chinese characteristics. It has been clearly pointed out in the 55th issue of the documentImplementation Opinion on Insisting and Improving the Principal Accountability System of Common Colleges under the Leadership of School Party Committee issued by General Office of the CPC Central Committee in 2014 that "the principal accountability system is an impartible organic integrity under the leadership of Party committee which must insists on the status of core of leadership of Party committee to guarantee the principal to legally perform duties and establish the working mechanism with unified leading of Party committee, division of labor between party and government and coordinated operation". [1]Therefore, the problems including lack of clean governance view, ambiguous probity awareness and the not-in-place main body responsibility for college probity education have the compelling obligations. Under the current situation under insisting on comprehensively strengthening Party self-discipline, it is required to implement clear responsibilities for each department layer of colleges and orderly operation and implement the probity standards of Party committee, administration, all the teachers and students for scientific research, all the ancillary staff and logistics staff as well as clear up the concept of responsibility main body and promote the full coverage of construction of clean college with no dead angles.

\section{Problem in Integrative Development}

Up to now, in colleges, the phenomenon of "mismatch" is still serious and the phenomenon of business first but party building second is also still serious. And it is hard to say the the construction of party conduct and clean governance has been really developed. In the four kinds of forms, the first form has not universally become the new normal. Therefore, to guarantee the comprehensive development of college clean government culture and probity education, we must promote the full coverage of probity education, comprehensive education with moral education and intellectual education and realize the coordinated development of professional development and probity education by complying with college features. According to the requirements for college clean culture, the integrity education of college shall blended in the textbooks and class teaching, uniform integrity education and course education. In the specific education and teaching activities, the basic theoretical courses and morals and ethics courses shall focus on party building, legal construction and probity content construction and shall also focus on integrating the probity contents into related specialized courses and basic courses of philosophy and social sciences of college as well as develop the special lectures, academic reports and special conditions with the "topic of probity" in various kinds of academic activities and take the contents of probity and clean governance as important contents in the training and study for cultivation of various kinds of student cadres, activist of party application and party members.[2] Well handle the relations among probity education, college moral education and professional education.

\section{CONNOTATION OF TRINITARIAN COLLEGE ClEAN Culture CONSTRUCTION}

To solve the problems including "dividend irrelevant theory", "mismatch" and "trochee", we need the new thought and new path for the full-coverage and integrative and coordinated development. We think that the college clean culture includes college probity party conduct culture, college clean teaching culture, college clean learning culture and college clean professional ethos culture, which can be said to be five-in-one in details and three-in-one in broad classification: clean governance of cadres, clean teaching of teachers and clean learning of students. What needs to be solved no matter for five-in-one or three-in-one include the problem of full coverage of probity construction and the problem of integrative development and collaborative promotion. Therefore, it will be just right for us to call it threein-one. So to say, the two concepts including college clean culture and college clean school spirit culture can be in common use. In details, aiming at the practical conditions of colleges, the college clean culture construction includes:

\section{A. Probity Party Conduct Construction}

The probity party conduct construction is the clean governance construction and is also the breakthrough of struggle against corruption of college. The probity party conduct construction requires all the party members and school party committee to be in the leading position in the manner of probity service which, according to the requirements in Code for Probity and Self-Discipline of Chinese Communist Party, includes culture of public and private interests: be scrupulous in separating public from private interests (public interests before private interests and wholehearted devotion to public duty); culture of upholding probity: upholding probity and refusing corruption (behave innocently and handle affairs justly); culture of valuing frugality: valuing frugality and refraining from luxury (hardworking and plain-living; diligent and thrifty); culture of dedication: suffer first (enjoy after; willing to sacrifice); put the strengthening of Party selfdiscipline into practice, follow party constitution and the party rules, have overall consciousness and core consciousness, solidly advance the works of combating corruption and upholding integrity of college, set up the clean and upright campus atmosphere and mobilize the construction of clean campus ethos through probity party conduct.

\section{B. Construction of Clean Political Atmosphere}

The clean political atmosphere means that all the leader, cadres and administrative staff shall possess upright thoughts and behaviors which include two layers: one being party 
member leaders and cadres and another being non-party member leader and cadres.

According to the requirements in Code for Probity and Self-Discipline of Chinese Communist Party, the clean culture construction of party member leaders and cadres includes: clean politics culture (be and keep the natural color as public servants), clean power exercise culture (rights for the people; exercise power for the maintenance of people 's fundamental interests), clean self-cultivation culture (promotion of ideology and morality state) and clean family regulating culture (leading to construct the clean family traditions). On such basis, the college party member leaders and cadres shall be led by secretary and shall also lead to construct the clean teaching style, learning style and professional ethos as well as lead to construct the clean political atmosphere.

It is important for the non-party member cadres of college to take principal as responsibility main body, insist on the construction of clean and upright campus culture, lead to guide all the administrative guidance department to serve all teachers and students, insist on being just and fair and honesty and trustworthiness. Form the clean political atmosphere and promote the construction of clean school spirit under the leading and organization of all leading cadres and administrative staff.

\section{Construction of Clean Teaching Style}

The construction of clean teaching style means that all teachers possess lofty probity culture and the education conducts of cultivation of people. It is put forward in the 18th National Congress of the China Communist Party that strengthens moral education and cultivates people and takes morality education first. As college teachers, they must strengthen their moral cultivation, possess the values of "upholding moral and being inclined to goodness, cultivate the fair and just vocational responsibility, keep the clean personal integrity with serious educational attitude, take the teaching and educating as their sacred mission, live up to the hope given by society to their occupation and take the "self-discipline and social commitment and demonstration in person" as the assessment standards for themselves. And then cultivate people with great love, uphold probity and devote them. In the education and teaching, the college teachers shall completely eradicate the utilitarian acts in works; and shall voluntarily resist the academic corruption in scientific researches; strictly enforce frugalness and completely eradicate all forms of misappropriation in the aspect of application of scientific research funds so as to form the good teacher teams with "probity education and everybody being responsible".

\section{Construction of Clean Learning Style}

The learning style is the direct embodiment of school spirit and the style and temperament of the teachers and student of the whole school with learning first and being supplemented by teaching. The construction of clean learning style lies in that all students shall possess clean learning objectives, learning contents and learning goals. The main body requires all students to blend clear discrimination, keeping on thinking, diligent in study and filial piety and probity, etc into daily life of college students under the leading of teachers and make the clean conducts normal state so as to form the good quality of probity and self-discipline; the students shall actively learn, observe laws and disciplines, keep honesty and trustworthiness, voluntarily observe rules and regulations, laws and regulations and social morality, uphold the honesty and integrity, cultivate the habit of observing law and discipline, establish the positive view of life and values, behave honestly, serve the society, establish the honest learning atmosphere and shall not learn for private interests so as to let the atmosphere of clean learning style flow on campus.

\section{E. Construction of Clean Professional Ethos}

The construction of clean professional ethos means that all the ancillary staff and logistics staff shall possess probity awareness. The college ancillary staff and logistics staff are the militia of college whose clean culture quality will impact the results of college probity careers and they shall act as the public servants for serving the college, possess the pure thoughts and clear consciousness of power and responsibility. They shall also observe the administrative morality requirements, set up good examples, serve the education of people, be diligent in working and responsible, observe party disciplines and laws of the country, maintain the social public interests and become qualified staff teams. On the service concepts, the college ancillary staff and logistics staff shall be close to all teachers and students, care about all teachers and students and serve all teachers and students, be respectful to laws and moral bottom line; have no distracting thoughts and be selfless in mind in the works; accomplish the goals of improving style, strengthening disciplines and resisting corruption and strive to become the demonstration college for promotion of clean culture according to the requirement of being scrupulous in separating public from private.

\section{POSITIONS AND MUtUAL RELATIONS AMONG ALL COLLEGE MAIN RESPONSIBILITY BODIES IN THE THREE-IN- ONE COLLEGE SCHOOL SPIRIT CONSTRUCTION}

\section{A. Party Conducts Determine the Nature of School Spirit, Lead the School Spirit Direction and Decide the Prospect and Development of School}

The party conducts and probity construction is in the leading position in the socialist spiritual civilization construction. The General Secretary Xi Jinping points out that the key of leading of college and improvement of party building of college lies in the party conduct construction which is also the embodiment of college spirits under socialism with Chinese characteristics. The college party committee shall grasp the school running direction based on new circumstances, new tasks and new goals, keep grasping the origin of force of reform based on the principle of moral composition and people cultivation first, correctly find the entry point of works, insist that the ideal and faith are the soul to guide the pace of progress of the party. The enhancement of ideal and belief education is the guarantee of political management of party, the source of power and foundation of Party members and cadres and the concrete embodiment of party style.[3] The party conduct determines the nature of school spirit, the party style leads the direction of school spirit and determines the 
prospect and development of school which possesses the demonstration and leading functions. To this extent, the party style will determine the socialist nature of college spirit.

\section{B. Political Atmosphere Impacts the Quality of School Spirit}

The impact of political atmosphere on quality of school spirit is conductive. In 2007, when Xi Jinping was the Secretary of Zhejiang Provincial Party Committee, he wrote in the text named delight of life is not just about minor matters that "the atmosphere is formed in upper level while the custom is formed in lower level. The life style and delight of life of leading cadres are not only related to the conducts and behaviors of themselves but also related to the prestige and image of party among the masses which possess the demonstration functions of "the below following the behavior of the above" for the formation of social morality and the cultivation of delight of life of the masses. "Enhance the moral education and values education for college students, insist on and strengthen ideal and faith, enhance the probity education policies, implement the integration and penetration, promote the construction of probity education base, voluntary service education for probity, enhance the education of Chinese traditional culture, integrity, filial piety and probity, sense of shame and sense of compassion, etc; and the system of administrative department plays key role in the impact on school spirit quality.

\section{Direct Impact of Teaching Style on School Spirit}

The direct impact of clean teaching style on school spirit is dominant. Teachers are the disseminators, practicers and guardians of college spirits and the demonstrators of teacher's ethics and teacher-training. As the saying goes, the essence of teacher quality is the teacher's ethics. The good teacher's ethics is the footstone for construction of college clean culture and the good teacher's style is the "guard stone" for cultivation of good learning style. As the frontline teachers and staff for students works of colleges, they shall set themselves an example for others, pay attention to teacher's ethics, insist on the faith that "who dare not be upright when the teachers have been upright", voluntarily accept the supervision of students, establish correct value guidance from all aspects of works, every word and conduct during the daily contact with students which will have direct impact on their practical actions. Therefore, we should actively build the cultural atmosphere of probity and keeping faith, put forth effort to construct the college teacher teams with both the strong politics and learning, both ethics and teaching excellence, upright morality and high quality, enhance the probity concept of college students and construction the honest and clean people education environment.

\section{Direct Impact of Learning Style on School Spirit}

The clean learning style has direct impact on clean school spirit which is in the main body position in the construction of college probity. Students are the shaper of college spirit and they shall, as students, be good at learning: learn with indefatigable zeal and be sensitive and eager to learn; be good at beauty-appreciation: have the sense of shame and sense of compassion; and thus form the heart of saintIrene and the attitude of emerging unstained from the filth as well as cultivate the quality of having integrity and being publicspirited. Therefore, we should form the clean learning atmosphere in school, form the correct values, eliminate the immaturity of mentality, avoid the impact of western culture and society on vulgar philosophy, get away from the problems including confusion about political conviction, ambiguous probity concept and twisted value orientation and should not let things drift so as to prevent students from becoming people abandoned by the society and becoming the seedling of corruption when they step in the society. [4]

\section{E. The Industry Has Important Impact on School Spirit}

The direct of industrial probity on clean school spirit is indirect. The school environment plays guiding role for students. All the ancillary staff and logistics staff shall abide by fair and just value orientation, have honesty and trustworthiness, be fair and just in handling affairs, be honest and clean, take students and teachers in first place and serve all teachers and students to gather power obtain approval so as to form the clean school atmosphere, realize the goals including people education through management, practice, environment and service and make students keep learning guarantee and learning motivation in the democratic and fair school environment. The self-reflection and emotional resonance of all teachers and students in the school can only be motivated by and the internalization of probity and self-discipline awareness can only be promoted by building the just and clean campus environment.

\section{REALIZATION PATH FOR DEVELOPMENT OF CONSTRUCTION OF COLLEGE CleAn CUlture}

Led by party committee, jointed with party and government; each performs its own functions; take gross root in first place; collaborate and cooperate; jointly promote.

\section{A. Grasping Construction of Clean System with Coordination of Party and Government to Accomplish Full Coverage of Probity Construction}

Conscientiously implement the four forms and transfer them into normal life state, normal learning state and normal political state. The colleges shall put forth efforts to implement the main body responsibility and supervision responsibility of discipline inspection committee for construction of party conduct and probity and further keep the relations between the party and masses and the cadres and masses closer. Carefully learn and implement the Code for Probity and Self-Discipline of Chinese Communist Party and the disciplinary punishment rules of Chinese Communist Party and implement through the conducts of college party members teachers and cadres so that they can lead to build the upright teaching and education working atmosphere. Enhance the intensity of clean education and clean culture construction and continuously promote the construction of clean campus. The first is the issue of system innovation which means the joint interview system for party and government of college gross root. When the object is party member, the secretary shall be the main body. When the object is non-party member, the dean shall be the main body. Take the establishment of various kinds of system construction of 
corruption prevention system, complete the party-government internal administration system, promote the various links in the construction of combating corruption and upholding integrity with all being linked with another, coordinate to grasp the party conducts and political atmosphere, achieve full coverage and solve the dividend irrelevant theory. The second is the dual-track system for award and punishment. The corrupt people shall be punished while the uncorrupted people shall be rewarded to guarantee the uncorrupted people to be satisfied on the aspect of materials and the spiritual level and guarantee the continuity of probity. The third is the main body responsible system. The college party committee shall be responsible for the deployment of work tasks for construction of clean governance and determination of assessment and punishment and award measures, formulation, organization and comprehensive implementation of probity plans. The principal and secretary of the party committee shall be the first persons responsible for the construction of school party conduct and clean governance who shall take full responsibilities for the construction of party conduct and clean governance. The leading group will sign different responsibility agreements with various teaching and research sections according to different labor divisions and will take main responsibility for the construction of clean governance for the works of branch offices as well as be responsible for the secretary of the party committee and the principal so as to strive to promote the level of system restriction and prevention of corruption.

\section{B. Grasping the Party Conduct, Teaching Style and Learning Style Through Coordination Between Party and Government}

Only the upright and just party conduct and political atmosphere can guarantee the clean and good teaching style and learning style. The first is the class preparation, class attending, class evaluation and learning assessment system under coordination between party and government: the system with joint class preparation, class attending, class evaluation, teaching assessment and learning assessment party branches and teaching and research sections; jointly grasp clean party conduct, teaching style and learning style. Solve the problems including mismatch and business before party building. During the progress of construction of party conduct and clean governance, dissolve the goals, define responsibilities with the person who takes charge shall take responsibilities, promote the construction of party conduct and clean governance level by level and the clean school education. The second is to enhance the construction of teaching style and efficiency. The efficiency of college student probity education is determined by the quality of teacher team which undertakes such works and the level of system supporting such works to a great extent. Therefore, the colleges shall establish the teacher teams with strong speciality and high noble character, employ full-time teachers, experts and scholars, etc to join the part-time staff teams for probity education works, put more emphasis on the teacher training works for probity education, enhance the probity quality of teaching and administrative staff, especially those who are engaged in ideological and political education works, give play to the spirit inspirational force of excellent teachers, determine to govern the style of "laziness, commonplace and corruption". The third is that the party and government departments actively develop various kinds of cultural activity forms and blend the probity education culture into the theory on school management, recreational and sports activities, teacher and student life and other aspects, blend the upright and clean culture into campus life, use the campus culture to enrich the faith of people and promote the spiritual level of people, build the clean and exquisite campus atmosphere and make the college students to voluntarily establish the probity concept in such atmosphere which will finally purify the school spirit and learning style of college.

\section{The Party Branches Shall Tightly Grasp the Issue of Ideology Safety}

The school party branch is the leading mechanism for the construction of party conduct and clean governance and the work of anti-corruption which shall intensify the ideology safety, greatly enhance the construction of work style of party member and cadres, and strengthen the party spirit. Therefore, during the construction of college party branches, the first is to actively promote the party branch battlewagon which requires to put forth efforts to construct learning-type party organization, construct the "demonstration" party branch and the party branch with "vigor growth" of students so as to further promote the primary-level party organization construction and activity innovation and effectively give play to the roles of primary-level party organization battlewagon. The construction of party branch battlewagon is mainly to promote the battlewagon for teaching reform and teaching and education. The active participation of party branch in teaching reform shall define the content of cultivation, how to cultivate people and shall implement the policy of morality education and morality education first. At the same time, the party branch shall conduct party affairs disclosure in strict accordance with the party affairs disclosure items of education system, and mainly disclose the work objectives of party branches, development of party members, charge of party membership dues, democratic appraisement for party members, implementation of responsibility system for construction of party conduct and clean governance and other contents. The second is to grasp the pioneer model leading role of party members which shall aim at the particularity of college party members, face to the levels of college party members and must combine with current actual situations to develop the probity education activities, help them establish correct concept of power, concept of political achievements and vocational views and keep the advancement and purity. Closely surround the living world and communication practices of "real-life persons" to construct the scientific and reasonable probity education concept, make the clean culture living, eliminate the internal driving force of corruption so as to restrain the breeding and spreading of corruption motivation.

\section{The Teaching and Research Sections Grasp Tightly on the Collaborative Promotion of Education and Teaching Quality and Teaching Reform}

The main responsibility body of education and teaching quality and teaching reform is the teaching and research section. Strengthen the intensity of party conduct and probity 
education, circle around the practical works of teaching and research section, insist on grasping implementation, grasping consolidation, grasping deepening, grasping education and teaching quality, grasping teaching reform; promote the deepgoing development of party building and construction of party conduct and clean governance, improve the probity for party members and cadres to be engaged in teaching and research management, grasp the construction of party conduct and clean governance and anti-corruption in teaching and research system so as to further standardize the industrial style construction of teaching and research system.

Firstly, the group leader of teaching and research group shall define the contents of responsibilities, lead to learn the theoretical knowledge about probity, master the forms of probity policy, grasp the party character, party conduct and party discipline education by taking them as important contents for probity education and enhance the probity. For one, we should solidly construct the line of defense of corruption rejection. Conduct thought supervision for the members of teaching and research groups, well handle the mass visit concerning aspect of probity of branch management department, timely find out problems, timely remind and timely report to the branch secretary. The second is the director of teaching and research sector who shall lead to learn the theory of probity, carefully organize the department to receive education on party conduct, party discipline and party character, enhance the ideological and political quality of cadre staff and implement the probity and clean governance works of party committee and discipline inspection commission and take the construction of party conduct and probity into the work plans and business learning. The third is to well grasp the learning, publicity and education of party branch of teaching and research sector and implement the contents and spirits of Probity Principles throughout the learning, publicity and education activities of party conduct, put the construction works of party conduct and probity on the agenda of teaching and research sector, enhance the construction of party conduct and clean governance and achieve the aspects including stressing party character, focusing on conducts and acting as example in the learning and education of party character, party conduct and party discipline. Take full charge of various kinds of publicity tools, deliver related conference spirits to party member staff, improve the ideological understanding and act as the example of clean teaching.

\section{CONCLUSION}

In a word, to construct the three-in-one clean culture of college, we must deeply realize the connotation of probity under strengthening of Party self-discipline and must set forth from the current practical situations of probity construction of college, give play to the join forces of various fields of party and government teaching, define the main responsibility body, coordinate all departments for party and government teaching, innovate the education system and mechanism, contents and methods, adapt to the modern college development states. Only in this way can we realize full coverage of college probity construction and can we observe the pure college sky.

\section{REFERENCES}

[1] Wang Ling. Requiring to Give Play to the Core Leading Functions of College Party Committee for Comprehensive Implementation of Strengthening Party Self-Discipline[J]. College Party Building and Ideological Education, 2016 (17) 王玲.贯彻全面从严治党要求发挥高 校党委领导核心作用 [J].学校党建与思想教育,2016(17)

[2] Xiong Xiaoqing. Method and Approach for College Probity Education Based on Effectiveness [J]. Study on Clean Governance Culture, 2011 (02) 熊小青.基于实效性的高校廉洁教育的方法与途径 $[\mathrm{J}]$. 廉政文化 研究, 2011(02).

[3] Zhang Jun. Enhancement of Party Building Works is the Fundamental Guarantee on Well Running the Colleges under Socialism with Chinese Characteristics[N]. Red Flag Manuscript 2016 (01) 张军.加强党建工作 是办好中国特色社会主义大学的根本保证[N].红旗文稿 2016（01）

[4] Jiang Xiaoping, Li Qingda, Qiu Aihui. Construction of College Probity Education System [J]. Journal of Hebei Academy of Young Administration Cadre, 2009 (04) 姜小平, 李庆达,邱爱辉.高校廉洁教 育体系的构建 $[\mathrm{J}]$.河北青年管理干部学院学报 2009 (04)

[5] Xiao Lingyun. Experience and Exploration of Further Promotion of College Student Probity Education under New Situations [J]. Studies in Ideological Education, 2011 (08) 肖凌云.新形势下深入推进大学生廉 洁教育的经验与探索 [J].思想教育研究,2011(08) 